\title{
Beauty Culture in Post-Reform Vietnam: Glocalization or Homogenization?
}

\author{
Hong Kong Nguyen \\ Graduate School of Asia Pacific Studies \\ Ritsumeikan Asia Pacific University \\ Beppu, Japan \\ (hongkongt.nguyen@gmail.com)
}

\begin{abstract}
This essay re-examines the global beauty culture and ideals as established by the West and continually reimagined worldwide through three primary lenses of race, gender, and political economy. Based on this understanding, it then delves into how the beauty culture in Vietnam has been shaped and transformed since the country conducted economic reforms in 1986 and has become more integrated into the global economy today.
\end{abstract}

Key words: beauty culture, beauty industry, globalization, Vietnam

$$
* * *
$$

"But it is worth noticing that for the people of Irian Jaya, Indonesianization may be more worrisome than Americanization, as Japanization may be for Koreans, Indianization for Sri Lankans, Vietnamization for the Cambodians, Russianization for the people of Soviet Armenia and the Baltic Republics. Such a list of alternative fears to Americanization could be greatly expanded, but it is not a shapeless inventory; for polities of smaller scale, there is always a fear of cultural absorption by polities of larger scale, especially those that are near by. One man's imagined community (Anderson, 1983) is another man's political prison." (Appadurai, 1990, 295)

\section{Introduction}

"Your nails say everything about you," wrote the giant calligraphy on the wall without paying homage to the person who said it, Tammy Taylor, an American nail professional well-established in the nail industry since 1983. Yet, except for this English quote, one could hardly find traces of any Western influence at this small Vietnamese nail salon in Hanoi- the staff did not speak English, the products were not imported from the United States but instead from China and South Korea, the desks and tables were crammed tightly to each other to conserve space, and the service cost the equivalent of two bowls of udon 
in Japan. Needless to say, as someone who had been away from home for a year, I had fallen far behind on the local beauty trends.

As I marveled silently at the meticulous way in which the twentysomething manicurist fixed my nails, I became engulfed in questions about the global beauty regimes and their far-reaching influence in small emerging economies such as Vietnam. I thought about my late mother who had grown up poor and never thought of painting her nails, let alone having someone else paint them, and about how all of this has changed in just one generation. As Vietnam's economy soared through the 1990s and continues to keep the growth momentum today, luxury high-rises and shopping malls have mushroomed across the country, imported goods have become more favorable, and the service industry has expanded accordingly to meet the demand of nearly 100 million people. The standardization of nail salons among many other beauty services in Vietnam over the past decade leads me to ask whether this is the beginning of cultural homogenization by globalization or a simple case of progress.

With this idea in mind, this essay reviews the global beauty culture, based upon which it then dissects the changes - their extent and drivers - in beauty ideals in Vietnam. The period of study is after Vietnam reformed its economy in 1986 and became increasingly integrated in the global economy in recent decades. The beauty culture has inspired a rich literature in sociology for it encompasses not just the way individuals claim and modify their bodies but also the way corporates and nations take hold of the symbols of progress and modernity (Jafar and Casanova, 2013).

\section{Global beauty: established and re-imagined}

Given that beauty itself evokes a sense of abstraction and transience, it is worth pondering about the geographical attribute of beauty: whether there exists a kind of global, transnational beauty or simply a host of local variations to the dominated Western beauty practices. It is undeniable that colonialism, capitalism, and globalization have altogether shaped and reproduced beauty cultures in different societies (Jha, 2016, Balogun and Hoang, 2013, Lee, 2012). On the one hand, globalization and technological progress have made many beauty practices, e.g. hair dying, hair extension, cosmetic surgeries, etc., popular across continents; on the other hand, these practices are not one and the same everywhere, such that their motivations or representations can be vastly different depending on the local contexts. Jafar and Casanova (2013) point out a noteworthy example in which female genital cosmetic surgery is seen as a practice popular in demand and with positive reception whereas female genital cutting or mutilation, which shares a similar description and outcome, is outlawed and deemed barbaric. Such discrepancy, which highlights the need to understand global as well as local power relations, brings attention to the constructivist nature of social phenomena, particularly beauty practices. This section briefly traces the constructions of beauty through three dominant and intertwining perspectives of race, gender, and political economy. 
Discourses of beauty have never been detached from racial politics (Craig, 2006, Jafar and Casanova, 2013). White skin, a stereotypical feature of the Western, or more specifically Caucasian, genetic makeup, is widely regarded as attractive and beautiful across cultures, whereas brown skin, tied to the nonWestern Other, is seen as undesirable and ugly (Torigoe, 2012, Picton, 2013, Li, Min, and Belk, 2008, Hunter, 2005, Craig, 2006, Ashikari, 2005). The valuing of whiteness, built on this binary perception of white as beautiful and non-white as otherwise, perpetuates the "racial hierarchies of bodies in postcolonial societies" (Jafar and Casanova, 2013, xix). At the same time, because these constructions of beauty are racialized, they necessarily reflect the contexts in which they arise. For instance, the Pan-Asian beauty ideal of white skin tone is not merely a pursuit of European whiteness but is a distinctive blend of Asian and European facial features (Yip, Ainsworth, and Hugh, 2019). Another line of studies even points out that racism and colorism, though inherently linked, are not exactly the same. The obsession with light skin in the Philippines, as Rondilla (2009) argues, is not merely about a pursuit of whiteness or purity but also about a desire to emulate the "Asian beauty ideal" which consists of porcelain white skin, straight black hair, and almond eyes. This desire is rooted in several factors ranging from the colonization of the Philippines by Spain, the United States, and Japan, the marginal position of the Philippines in the Asian region, to its role as a major labor exporter and the continual exposure to Western media (Rondilla, 2009). The organic growth of an appreciation for white or light skin, a move almost independent of the blackwhite dynamics of race, is also seen in East and South Asia (Vaid, 2009). In particular, having a light complexion among Indians is highly valued and not necessarily an issue of racism because it carries significant symbolic capital in marriage negotiations, many of which take place under the arranged form (Vaid, 2009, Dhillon-Jamerson, 2019). The consumption of whitening cosmetics in Japan is similarly not about a craving of an Western value or an expression of traditional Japanese female beauty; it is an act aimed at presenting the Japanese form of whiteness, and thus, symbolizes Japanese identity at large (Ashikari, 2005). As can be seen, discussions of race in beauty culture are inevitably tangled in talks about skin tones politics and colorism. Yet, they do highlight the diversified ways - whether that be a country's history, societal hierarchy, or nationalism - through which the local beauty cultures are shaped. The ultimate origin of our values of beauty and the beauty standards, as Bergen (2013) reflects on the differences in skin tone and body hair between Americans and Cambodians, may be after all not all that clear for no force can singlehandedly leave such an influence.

Just as race is a popular lens through which beauty ideals are analyzed, gender and feminist theories also provide a fertile ground for scholars in the field. The body, according to Michel Foucault and feminist scholars, is a site of direct social control (Bordo, 1989, Brook, 1999). Beauty standards exist to regulate the bodies and lives of women, evidenced by the numerous beauty pageant contests around the world (Jha, 2016). As such, the construction of the female body in different societies has been of critical interest to 
scholars, with case studies zooming on the intersectionality of race and beauty among young female adolescents in Ecuador (De Casanova, 2004), the perception of body image among women of African descent (Ofosu, Lafreniere, and Senn, 1998), the ways women assert power through resisting and accommodating mainstream female hair norms in the United States (Weitz, 2001), the shaping of girls' bodies in Finnish schools (Harjunen, 2002), or the representation of women's bodies in Nigeria and Vietnam (Balogun and Hoang, 2013), to name a few. The common approach in many of these studies is to break down the power struggles between men and women, to examine the dieting and cosmetic surgery as well as the increasingly significant role of the media and socio-political movements in shaping the discourses on female bodies and femininity. A textual analysis of three makeover programs in the United States calls attention to the commodification of the female body and the continually changing images of acceptable beauty against which women are measured and judged (Gallagher and Pecot-Hebert, 2007). Global beauty standards, from a gender perspective, appear largely unchanged over centuries, even though women have gained power in the workplace and at home. Many beauty ideals regarding the shape of their body, their weight, the length of their hair, the amount of body hair permitted, etc. remain ludicrous to uphold for women, who today are still subject to the male gaze and a host of societal expectations.

Beyond the discourses on race and gender in beauty culture is the inevitable role of the global and local political economy. In studying the geopolitics of beauty in South Korea, Lee (2012) focuses on the normalization of plastic surgery by two waves of force: consumer-popular culture and the country's own neoliberal policies. Here, the two industries of mass media and the beauty industry are identified as the ultimate drivers of women's self-image, and subsequently, their cosmetic surgery consumption (Lee, 2012). Mass media, which includes magazines, newspapers, televisions, and movies, serves an important channel for propagating beauty standards. According to a content analysis of more than 5,500 female models in four top beauty and fashion magazines from 12 countries and regions, even though the overall image of beauty was found to be relatively independent of Western influence across cultures, there is a domination of Western models on the cover pages (Yan and Bissell, 2014). Such representations undoubtedly contribute to perpetuating the Western-established standards of beauty and the association of Western models/faces as high-fashion in comparison with the non-Western counterparts. Thriving off the works of mass media, the beauty industry feeds on consumers' craving for cosmetic products that make them look younger, whiter, or more beautiful — as dictated by the industry itself (Jha, 2016). In this sense, beauty, health, and media corporations all constitute important players in the fight for regulating and controlling bodies, especially of women.

The representation of local beauty at a global level perhaps reaches its apex in the form of global beauty pageants. Even as the viewership of several televised beauty contests today has plummeted from its height in the mid-1960s (Fitzgerald, 2018, Maas, 2019), these shows remain widespread as they provide a 
commercial platform for the making and display of judgements of cultural value (Wilk, 1995). It is where the configuration of the female gender as this otherness is formed and kept alive. Even more important is how, as Parameswaran (2005) argues, understanding the mass media narratives about Indian global beauty queens could shed light on "India's transformation from a protected quasi-socialist economy into a burgeoning location for the production and sale of global commodities" (421).

This section has explored the three dominant perspectives - race, gender, and political economy in analyzing beauty ideals across cultures. It has offered a glimpse into the voluminous research on the constructions of beauty standards, the female bodies, and a global beauty culture, all the while highlighting some of the causes, the key players, and their goals. With this background in mind, the next section focuses on the presence of such elements in a specific context, Vietnam, which is a lower-middle-income country with a thousand year of Chinese domination (111 BC to 938 AD), a hundred year of French colonialism (1887-1954), and decades of war against American imperialism (1955-1975).

\section{Vietnamese beauty standards: from traditions to modernity}

Vietnam presents an appropriate case study of a postcolonial society in which its 1986 economic reforms and subsequent liberalization policies have transformed the livelihoods of the local people as well as their world views (Vuong, 2019, Vuong and Napier, 2015). The booming of the Vietnamese beauty market in recent years is fueled by the rise of a middle-income class - which makes up one-third of the population - and arguably, by a large and young population that is increasingly exposed to beauty practices in more developed countries such as the United States, Europe, South Korea, and Japan. Similar to other Southeast Asian nations, Vietnam is facing both the direct effect of Western media influence as well as its trick-down effect - e.g. the adaptations of Western-originated music videos, movies and commercials by countries such as South Korea, Thailand, and Malaysia where the influence of American culture is stronger (Bergen, 2013). The result is, statistically speaking, the beauty market in Vietnam, though valued at between USD2.3 billion and USD3.7 billion a year (Vien Thong, 2019, Vietnam News, 2019), is 90\% dominated by foreign companies, with South Korean companies accounting for 22\%, Japan 13\%, France 12\%, Thailand 12\%, and the United States 12\% (B\&Company, 2019). The money spent on cosmetic imports was even higher, at USD6 billion in 2018, a threefold hike from 2016 (Nikkei, 2019), hinting at a fast-growing market and ever-rising demand for imported beauty products. It is clear that this has not always been the case, but are the growing wealth and product availability the sole transformational factors here?

When one looks back at the conventional beauty ideals as they have been known in Vietnam for centuries, one would be surprised to learn that the ancient emphasis is not on physical appearance but on the inner virtues. A Vietnamese proverb puts this succinctly: "Cái nết đánh chết cái đẹp" (translated as Virtue/Character is better than Beauty). Yet, just as how, in contemporary discourse, the female body is 
seen as the battleground for religious ideologies, national and political institutions, and media and beauty corporates, the female identity in traditional Vietnamese society is also subject to a set of rules. As the Confucian moral code dictates, Vietnamese women have to abide by the "Three Obediences" (tam tòng), which include obeying her father before marriage, obeying her husband once married, and obeying her son after her husband passes away, in addition to attaining the "Four Virtues" (tú đúc) of moral conduct (đúc), proper speech (ngôn), fair/dignified appearance (dung), and diligence (hanh) (Taylor and Choy, 2005). No classical texts in Confucianism or Vietnamese folk religion can be found to distill the precise content of "fair/dignified appearance," and one can safely assume that this appearance is nonetheless rooted in the need to keep face - i.e. dignity and prestige - for one's family rather than in the maintenance of personal beauty for oneself. In other words, the shifting attitudes on beauty in Vietnam have marked a departure from traditional influences and a move closer to a consumer culture.

This is not to say that one cannot find traces of description regarding the beauty standards-once again imposed on women - in feudal Vietnamese society. In the famous epic poem The Tale of Kieu ("Truyện Kiều") by Nguyen Du, the female protagonist, Thuy Kieu, is said to exemplify the ultimate feminine beauty for she possesses as much outward as inward beauty, with her talent unrivalled, skin as white as snow, and hair smoother than cloud ${ }^{1}$. Equally noteworthy is how, throughout Vietnamese history, the female submission under Confucian moral codes has not been without contest. Perhaps it is the emphasis on virtue cultivation that underlies the valuing of talented, strong, and decisive women as represented in Vietnamese myths, legends and history (Tran, 2002). Notable examples include the fight against Chinese domination over Vietnam in AD 40 by the Trung sisters (Hai Ba Trung) and the feminist spirit espoused by the female poet Ho Xuan Huong in the $18^{\text {th }}$ century. What is clear is, whether the standards be set on one's physical appearance or inner beauty, these rules are heavily gender-biased for subjecting solely women to their rigidity.

Understanding Vietnam's traditions helps us situate the changes today in the proper context. Vietnam, despite its thousand-year history, is still seen as a young country in two ways: its political independence and national unification only happened in 1975, and $70 \%$ of its population is under 35 years of age (Salomon and Vu, 2007). The move away from traditional beauty ideals appears to be the result of a rapid growth in private wealth, especially in urban areas, which contributed to the country's smooth transition from a centrally-planned economy into a robust consumer society (Nguyen et al., 2019). In an examination of young Vietnamese's consumption practices, Nguyen, Özçaglar-Toulouse, and Kjeldgaard (2018) note a rejection of the communist identity and government-promoted lifestyle in the everyday consumption practices, that the acts of buying products suitable to young consumers' taste constitute a kind

\footnotetext{
${ }^{1}$ The original line is: "Mây thua nước tóc, tuyết nhường màu da” (Nguyen, 1820).
} 
of "individualization through self-emancipation, self-enrichment, and self-actualization" (490). What ensues is a dichotomy in government politics: on the one hand, it promotes Marxism-Leninism and condemns bourgeois consumption, but on the other hand, it also depoliticizes and even normalizes consumption in its promotion of the middle-class as a "modern, civilized, and patriotic" demographics in contemporary society (Nguyen-Marshall, Drummond, and Bélanger, 2012, 21). Seen through this lens of Vietnam's political economy, the rise of a consumer beauty culture appears inevitable, though not necessarily caused by globalization.

Contemporary beauty practices in Vietnam, as I have pointed out above, are influenced by practices originated from both the West (the United States and Europe) and East Asia. Yet, exogenous cultures are not the sole drivers of the local changes. The structure of cosmetics spending by Vietnamese gives us hint on the beauty areas that receive the most attention: skin care and make-up products (B\&Company, 2019). Vietnamese consumers are spending heavily on sunscreen and various facial care products that range from cleanser, toner, moisturizer, to whitening cream. Once again, as observed in other cultures, beauty is defined by one's skin tone - the more fair, lighter or whiter the skin color, the more beautiful one is. This perception, similar to what scholars have noted in the cases of the Philippines (Rondilla, 2009), India (Vaid, 2009), or Japan (Ashikari, 2005), is not necessarily tied to Vietnam's colonial history but may be attributed to its own ancient depiction of beauty.

At the same time, it is important to note that the changes in beauty perception are not simultaneous throughout the whole of Vietnam. For instance, an article published on May 21, 1973 in the New York Times revealed the craving for American aesthetics such as round eyes, bigger nose, dimple cheeks, a cleft chin, bigger breasts, hips and thighs, and hence, a boom in the local cosmetic surgery industry (Denman, 1973). The demand for cosmetic surgery was in fact so high that southern Vietnam at the time recorded a shortage of plastic surgeons (Denman, 1973). This was not the case in the northern region where war still ravaged until 1975 and food shortage persisted through 1989. The development in South Vietnam perhaps foreshadows what would to become of a society once peace and economic prosperity are realized.

At first appearance, I had surmised that Vietnamese beauty practices are being homogenized by global media and multinational conglomerates, such that local consumers now want to same things that consumers in the developed world have. While wanting the same things is nothing to be demoralized, I feared about the dissipating local beauty culture. What I have witnessed is the seamless importation of foreign beauty ideals, which may sometimes be jarring, or even contradictory, to what the Vietnamese people have come to known - a phenomenon defined as "cultural additivity" (Vuong et al., 2018). Nonetheless, in examining these developments in an academic manner, I had come to realize how the pursuit of non-Vietnamese beauty ideals is as much a reflection of a robust market as an expression of selfactualization and progress in modern times. 


\section{Conclusion}

This essay has reviewed the scholarship on beauty ideals across culture, focusing on the three dominant discourses of race, gender, and political economy on beauty. It notes a prolific literature on the intersectionality of race, class, and gender in the configuration of beauty ideals, particularly for the female bodies. Extant research has also paid significant attention to the role of mass media and the beauty industry in regulating and reinforcing stereotypical beauty standards, as established in the West.

In the second half, the essay zooms in on the transformation of perceptions toward beauty ideals in Vietnam, a country that moved from one of the world's poorest to a lower-middle income country in just three decades. While the constructions of beauty in postcolonial societies tend to be both racialized and gender-biased, in Vietnam, it appears that gender-biased conventions and mass narratives remain a dominant force. Here, the female bodies remain the site where beauty standards are shaped, where national identities are formed, maintained, and resisted. This process is facilitated by a young population with high demand for products that give them voices beyond the communist setting as well as by a rapid surge in private wealth of the middle-class over a relatively short period. The case of beauty culture in post-reform Vietnam, therefore, is not one of homogenization but indeed of glocalization - the internalization of global practices and values in a local environment.

\section{References}

Appadurai, Arjun. 1990. "Disjuncture and difference in the global cultural economy." Theory, culture \& society 7 (2-3):295-310.

Ashikari, Mikiko. 2005. "Cultivating Japanese whiteness: The 'whitening' cosmetics boom and the Japanese identity." Journal of Material Culture 10 (1):73-91.

B\&Company. 2019. "A dynamic cosmetics market in Vietnam." B\&Company, accessed January 29, 2020. https://www.b-company.jp/en/2019/09/17/a-dynamic-cosmetics-market-in-vietnam/.

Balogun, Oluwakemi M., and Kimberly Kay Hoang. 2013. "Refashioning Global Bodies." In Global Beauty, Local Bodies, edited by Afshan Jafar and Erynn Masi de Casanova, 1-21. New York: Palgrave Macmillan US.

Bergen, Kaija. 2013. "Most Days I'm Beautiful." In Global Beauty, Local Bodies, edited by Afshan Jafar and Erynn Masi de Casanova, 83-88. New York: Palgrave Macmillan US.

Bordo, Susan R. 1989. "The body and the reproduction of femininity: A feminist appropriation of Foucault." In Gender/body/knowledge: Feminist reconstructions of being and knowing, edited by Alison M Jaggar and Susan R Bordo. New Brunswick, NJ: Rutgers University Press. 
Brook, Barbara. 1999. "Feminist perspectives on the body." In Feminist Theory and the Body: A Reader, edited by Janet and Margrit Shildrick Price. London: Longman.

Craig, Maxine Leeds. 2006. "Race, beauty, and the tangled knot of a guilty pleasure." Feminist Theory 7 (2):159-177. doi: 10.1177/1464700106064414.

De Casanova, Erynn Masi. 2004. "“No Ugly Women”: Concepts of Race and Beauty among Adolescent Women in Ecuador." Gender \& Society 18 (3):287-308. doi: 10.1177/0891243204263351.

Denman, Della. 1973. "In Vietnam, With Plastic Surgeons in Demand, Cosmetic Surgery Thrives." The New York Times, accessed January 29, 2020. https://www.nytimes.com/1973/05/21/archives/invietnam-with-plastic-surgeons-in-demand-cosmetic-surgery-thrives.html.

Dhillon-Jamerson, Komal K. 2019. "Marketing Marriage and Colorism in India." In Race in the Marketplace: Crossing Critical Boundaries, edited by Guillaume D. Johnson, Kevin D. Thomas, Anthony Kwame Harrison and Sonya A. Grier, 121-136. Cham: Springer International Publishing.

Fitzgerald, Toni. 2018. "Miss America 2019 Ratings: Viewership Falls Again For Revamped Pageant." Forbes, accessed January 28, 2020. https://www.forbes.com/sites/tonifitzgerald/2018/09/10/missamerica-2019-ratings-viewership-falls-again-for-revamped-pageant/\#35f4453f5215.

Gallagher, Amanda Hall, and Lisa Pecot-Hebert. 2007. "“You Need a Makeover!”: The Social Construction of Female Body Image in "A Makeover Story", "What Not to Wear", and "Extreme Makeover"." Popular Communication 5 (1):57-79. doi: 10.1080/15405700709336785.

Harjunen, Hannele. 2002. "The construction of an acceptable female body in Finnish schools." In Gendered and Sexualised Violence in Educational Enviroments, edited by Vappu Sunnari, Jenny Kangasvuo and Mervi Heikkinen, 81-94. Oulu, Finland: Oulu University Press.

Hunter, Margaret L. 2005. Race, Gender, and the Politics of Skin Tone. London: Routledge.

Jafar, Afshan, and Erynn Masi de Casanova. 2013. "Bodies, Beauty, and Location: An Introduction." In Global Beauty, Local Bodies, edited by Afshan Jafar and Erynn Masi de Casanova, xi-xxv. New York: Palgrave Macmillan.

Jha, Meeta. 2016. The Global Beauty Industry. New York: Routledge.

Lee, Sharon Heijin. 2012. "The (Geo)Politics of Beauty: Race, Transnationalism, and Neoliberalism in South Korean Beauty Culture." Doctor of Philosophy (American Culture) Dissertation, The University of Michigan.

Li, Eric P.H., Hyun Jeong Min, and Russell W. Belk. 2008. Skin Lightening and Beauty in Four Asian Cultures. In NA - Advances in Consumer Research, edited by Angela Y. Lee and Dilip Soman. Duluth, MN: Association for Consumer Research. 
Maas, Jennifer. 2019. "Fox’s 'Miss Universe’ Ratings Fall 18\% From Last Year's Competition, Tying AllTime Low." The Wrap, accessed January 28, 2020. https://www.thewrap.com/miss-universe-tielow-ratings-fox-supergirl-crisis-infinite-earths-cw/.

Nguyen-Marshall, Van, Lisa B. Welch Drummond, and Danièle Bélanger, eds. 2012. The Reinvention of Distinction: Modernity and the Middle Class in Urban Vietnam, ARI - Springer Asia Series: Springer.

Nguyen, Du. 1820. Truyen Kieu [The Tale of Kieu].

Nguyen, Nhat Nguyen, Nil Özçaglar-Toulouse, and Dannie Kjeldgaard. 2018. "Toward an understanding of young consumers' daily consumption practices in post-Doi Moi Vietnam." Journal of Business Research 86:490-500. doi: https://doi.org/10.1016/j.jbusres.2017.10.002.

Nguyen, To Hong Kong, To Viet Ha Nguyen, Thu Trang Vuong, Manh Tung Ho, and Quan Hoang Vuong. 2019. "The new politics of debt in the transition economy of Vietnam." Austrian Journal of SouthEast Asian Studies 12 (1):91-110. doi: 10.14764/10.ASEAS-0015.

Nikkei. 2019. "Hong Kong's Watsons dives into Vietnam's crowded beauty market." Nikkei Asian Review, accessed January 29, 2020. https://asia.nikkei.com/Business/Companies/Hong-Kong-s-Watsonsdives-into-Vietnam-s-crowded-beauty-market.

Ofosu, Helen B., Kathryn D. Lafreniere, and Charlene Y. Senn. 1998. "Body Image Perception among Women of African Descent: A Normative Context?" Feminism \& Psychology 8 (3):303-323. doi: $10.1177 / 0959353598083005$.

Parameswaran, Radhika. 2005. "Global Beauty Queens in Post-Liberalization India." Peace Review 17 (4):419-426. doi: 10.1080/10402650500374702.

Picton, Oliver. 2013. "The Complexities of Complexion: A Cultural Geography of Skin Colour and Beauty Products." Geography 98:85-92.

Rondilla, Joanne L. 2009. "Filipinos and the color complex: Ideal Asian beauty." In Shades of difference: Why skin color matters, edited by Evelyn Nakano Glenn, 63-80. Palo Alto, CA: Stanford University Press.

Salomon, Matthieu, and Doan Ket Vu. 2007. "Doi Moi, education and identity formation in contemporary Vietnam." Compare: A Journal of Comparative and International Education 37 (3):345-363. doi: 10.1080/03057920701330222.

Taylor, Rodney Leon, and Howard Y. F. Choy. 2005. The Illustrated Encyclopedia of Confucianism. vol. 1. New York, NY: The Rosen Publishing Group.

Torigoe, Chie. 2012. "Whiteness discourse in Japan: The construction of ideal beauty and racial Others in cosmetic surgery advertisements." 西南学院大学学術研究所 (第 52 巻第 3 号抜刷). 
Tran, Vi. 2002. "Women's Heart of Sorrow: Versions of the Truyen Kieu in the Works of Duong Thu Huong and Le Ly Hayslip." Master of Arts (MA), English, Eastern Illinois University (Masters Theses. $1525)$.

Vaid, Jyotsna. 2009. "Fair enough? Color and the commodification of self in Indian matrimonials." In Shades of difference: Why skin color matters, edited by Evelyn Nakano Glenn, 148-165. Palo Alto, CA: Stanford University Press.

Vien Thong. 2019. "Affluence, e-commerce make Vietnam a lucrative cosmetics market." VnExpress, accessed January 29, 2020. https://e.vnexpress.net/news/business/industries/affluence-ecommerce-make-vietnam-a-lucrative-cosmetics-market-3967651.html.

Vietnam News. 2019. "VN cosmetics market's shining potential." Vietnam News Agency, accessed January 29, 2020. https://vietnamnews.vn/economy/519921/vn-cosmetics-markets-shiningpotential.html.

Vuong, Quan-Hoang, Quang-Khiem Bui, Viet-Phuong La, Thu-Trang Vuong, Viet-Ha T. Nguyen, ManhToan Ho, Hong-Kong T. Nguyen, and Manh-Tung Ho. 2018. "Cultural additivity: behavioural insights from the interaction of Confucianism, Buddhism and Taoism in folktales." Palgrave Communications 4 (1):143. doi: 10.1057/s41599-018-0189-2.

Vuong, Quan Hoang. 2019. "The financial economy of Viet Nam in an age of reform, 1986-2016 " In Routledge Handbook of Banking and Finance in Asia, edited by Morgan Volz and Yoshino. London, UK: Routledge.

Vuong, Quan Hoang, and Nancy K Napier. 2015. "Acculturation and global mindsponge: an emerging market perspective." International Journal of Intercultural Relations 49:354-367.

Weitz, Rose. 2001. "WOMEN AND THEIR HAIR: Seeking Power through Resistance and Accommodation." Gender \& Society 15 (5):667-686. doi: 10.1177/089124301015005003.

Wilk, Richard. 1995. "The local and the global in the political economy of beauty: From Miss Belize to Miss World." Review of International Political Economy 2 (1):117-134. doi: 10.1080/09692299508434312.

Yan, Yan, and Kim Bissell. 2014. "The Globalization of Beauty: How is Ideal Beauty Influenced by Globally Published Fashion and Beauty Magazines?" Journal of Intercultural Communication Research 43 (3):194-214. doi: 10.1080/17475759.2014.917432.

Yip, Jeaney, Susan Ainsworth, and Miles Tycho Hugh. 2019. "Beyond Whiteness: Perspectives on the Rise of the Pan-Asian Beauty Ideal." In Race in the Marketplace: Crossing Critical Boundaries, edited by Guillaume D. Johnson, Kevin D. Thomas, Anthony Kwame Harrison and Sonya A. Grier, 7385. Cham: Springer International Publishing. 